upon the relation of this quantity to the value of the velocity gradient. In a recent theoretical paper, Peterlin shows that random orientation can only be asserted if the suspended particles are shorter than $10^{-6} \mathrm{~cm}$. Lauffer ${ }^{11}$ suggests that the length of the virus particle is of the order of $10^{-4} \mathrm{~cm}$., which would exclude the assumption of random orientation involved in his use of Kuhn's equation. Since Kuhn's equation can only be applied when the particles are smaller than $10^{-6} \mathrm{~cm}$., it is clear that its use in interpreting measurements of the viscosity of virus solutions should be discontinued.

Only measurements made in a cylinder apparatus, where simultaneous control and determination of the state of orientation are possible, can be expected to be significant when the particles are so large as to be considerably orientated at low rates of shear.

Quite apart from the high rate of shear which inevitably obtains in them, capillary viscometers are quite unsuited for the study of anomalous systems. In these systems the viscosity depends upon the rate of shear. In a capillary viscometer the rate of shear, and with it the viscosity of an anomalous liquid, varies across the lumen from a high value near the walls to zero on the axis of the flow tube. No precise significance can be attached to a measured 'viscosity'.

G. I. Taylor ${ }^{13}$ reported that in his model experiments some time was required for the establishment in a steady state of the motions of precession of the particles. Peterlin ${ }^{14}$ points out that even when the particles are so small as those of the virus, this process may require some seconds. All theoretical formulæ which are not concerned with a variation of viscosity with time must assume that this steady state is reached. In a cylinder apparatus, unlimited time may be allowed for its attainment. But in a capillary viscometer, a given element of volume of the liquid remains in the flow tube only for a fraction of a second, and time may not be allowed for the steady state to be established.

Since the variation of the velocity gradient across the lumen of the capillary is accompanied by a variation in the state of orientation, capillary methods are also unsuited for the measurement of double refraction of flow. The double refraction of flow of the suspension as a whole can only be referred to the birefringence of the individual particles if an independent measurement of the state of orientation is also possible. Comparisons between different systems are only valuable if they can be made in corresponding states of orientation. When a cylinder instrument is used, the angle of isocline may be measured as well as the double refraction, and provides the necessary control.

The methodological problem is summed up in the statement that the viscosity of a suspension is most emphatically not a simple physical property of that suspension, as it would be of a Newtonian liquid. The energy dissipated depends upon the type and upon the rate of flow; so the recorded viscosity depends upon the method of measurement, and especially upon the rate of shear which is employed. A statement of the 'viscosity' of an anomalous system which does not include reference to these controlling factors has little meaning.

\footnotetext{
${ }^{1}$ Bawden, F. C., and Pirie, N. W., Proc. Roy. Soc., B, 123, 274 (1937)

${ }^{2}$ Bernal, J. D., and Fankuchen, I., Nature, 139, 923 (1937).

${ }^{3}$ Robinson, J. R., Dissertation, Cambridge (1938).

- Robinson, J. R., in the Press. See Abstract, Proc. Roy. Soc., A, 169, S, 156 (1938)

${ }^{5}$ Kuhn, W., Kolloidzeit., 62, 269 (1933).

'Staudinger, H., Z. phys. Chem., A, 153, 391 (1931).

"Staudinger, H., "Die hochpolymeren organischen Verbindungen, Kautschuk und Zellulose" (Berlin, 1932).

${ }^{8} \mathrm{Kuhn}, \mathrm{W} .$, Z. phys. Chem. A, 181, 1, 427 (1932).

- Lauffer, M. A., Science, 87, 469 (1938).

${ }^{10}$ Frampton, V. L., and Neurath, H., Science, 87, 468 (1938).

11 Lauffer, M. A., J. Biol. Chem., 128, 443 (1939).

${ }^{12}$ Neurath, H., and Saum, A. M., J. Biol. Chem., 126, 435 (1939).

13 Taylor, G. I., Proc. Roy. Soc., A, 103, 58 (1923).

14 Peterlin, A., Z. Physik, 111, 232 (1938).
}

\title{
Lazzaro Spallanzani
}

\section{Celebration at Pavia}

$\mathrm{O}^{\mathrm{N}}$ April 11-15, the University of Pavia honoured the memory of one of its greatest sons, Lazzaro Spallanzani (1729-1799). The celebrations took the form of a special meeting of the Italian Society of Experimental Biologists, to which a number of representative foreign men of science were invited, with closely associated and contemporaneous meetings of the Italian Botanical and Geological Societies, as well as a congress of veterinarians.
On the morning of April 11, in the Great Hall of the University, with a Duke of the Royal House presiding, there assembled a most colourful company to listen to the oration given by Prof. Botazzi of Naples, and to receive the greetings and congratulations conveyed from scientific bodies and institutions in foreign countries by their official delegates. Thereafter the company passed along cool cloisters bedecked by fine statues and plaques to the Pavian worthies-Volta, Golgi, among 
others-to the quadrangle where the shrouded marble figure of Spallanzani waited. The unveiling itself was a simple act, and then it seemed that relative merit had at last been recognized, for the fine new monument dominated its environment; then to lunch, given by the Mayor of Pavia in the splendid and attractive Almo Collegio Borromeo. Then, somewhat reluctantly, for the entertainment was rich and satisfying, on to the Aula Spallanzani in the Zoological Institute, formerly a palace and, so far as university department buildings go, still most palatial. If the place where work is done affects its quality, then no wonder great discoveries have been made in Pavia.

All through the afternoon, specialists in different fields of biology, each acknowledged in his turn the indebtedness of his particular branch of science to Spallanzani. It was an inspiring experience to stand and speak where he had stood and taught. His mantle seemed to brush one's shoulder. As speaker followed speaker, it seemed that the history of science in the eighteenth century was a record of Spallanzani's own work: 1754-60, a teacher of logic, metaphysics and Greek in the University of Reggio ; 1760, lecturer in the Natural History Department of the University of Modena ; 1769, invited to the chair of natural history in Pavia, a post which he adorned until his death. Whilst at Modena he had been active in experimentation designed to test the reality of spontaneous generation, and his contributions concerning the anatomy and physiology of the circulatory system were of such quality as to justify Haller's dedication to him of one of the volumes of his "Treatise of Physiology". With the greater opportunities that Pavia offered, his interests passed rapidly from problems of regeneration to the origin of springs; to the systematics of the Protozoa, to the functions of chlorophyll, to tissue respiration, to the role of the sperm in fertilization, to the chemical aspects of digestion, whilst at the same time work carried out on journeys along the Mediterranean coast earned for him the title of the founder of volcanology. $\mathrm{He}$ augmented the content of each and every subject that he touched, and many of his discoveries, being made before their quality could be assessed, had long to lie dormant until men's minds were later turned in their direction.

It was not surprising, therefore, to listen, during the afternoon and the following three days, to a series of papers dealing with the most diverse of subjects, every one of them nevertheless testifying to the fact that Spallanzani had made notable contributions to each and all. Abderhalden (Halle) on digestion ; Federley (Helsingfors) on the chromosome and gene; Ruggles Gates (London) on the nature of genic differences; Camara (Lisbon) on the branched chromosome ; von Muralt (Bern) on the relationship of Spallanzani and Albrecht von Haller ; Pupilli (Bologna) on the physiology of the circulatory system ; Crew (Edinburgh) on artifical insemination and its uses in the experimental study of the species problem ; TimoféeffRessovsky (Berlin) on genetics and evolution; Jucci (Pavia) on physiological genetics ; Montalenti (Bologna) on tissue respiration; Brunetti (Pavia) on animal electricity ; Baltzer (Bern) on hybrid grafts and partial homology of nuclei from different species, were among those who contributed to the homage that was so gladly paid. Meanwhile the botanists, geologists and veterinarians were similarly occupied, so that the air of Pavia must have been heavily laden with well-merited eulogy of Spallanzani.

The veterinarians in their meetings dealt entirely with the techniques and possible uses of artificial insemination. It will be remembered that Spallanzani, being greatly impressed by the results of the artificial insemination of trout eggs by Waltheim, succeeded in 1779 in artificially inseminating a bitch. It is a great pity that at 
this meeting there was no one from the U.S.S.R. Had there been, they could have been reminded that they, who have exploited this technique more than any other people, are greatly indebted to the Italian Spallanzani, and their hosts could have been given further reason for their rejoicings by the knowledge that Spallanzani's early sowings had produced so abundant a harvest.

The foreign delegates were housed in the Collegio Ghislieri and in the Almo Collegio Borromeo. 'Housed' is certainly the wrong word, for the hospitality they received was so warm and so friendly, and the accommodation itself so welcoming, that they who had come as strangers, left as friends.

During the days of the congress when for brief intervals the clamour of discussion died down, there were pleasant excursions to the Certosa di Pavia, a Carthusian monastery crowded with works of art; to the town of Pavia itself; and to the
Spallanzani Museum at Reggio. In addition there were evening concerts, exquisite yet informal, such as could only be enjoyed in Italy, in the rooms of the Circolo del Littorio. The foreign delegates came away full of admiration and gratitude, entertaining the wish that all congresses, if not meeting in Italy where they do these things so well, should at least be constructed on the Italian model.

This celebration was notable also for the appearance of the first number of a new journal, Scientica Genetica (see Nature of April 22, p. 676). This is a matter of some considerable interest for it truly marks a stage in the development of this science in Italy. A rapidly growing school exists and the stage of its development is indicated by the recognition of the need for the publication of a specialist scientific journal which will cater primarily for the geneticists of the Latin-speaking countries.
F. A. E. CRew.

\section{Obituary Notices}

\section{Sir Frank Dyson, K.B.E., F.R.S.}

$I^{T}$ is with much regret that we record the death at sea on May 25 of Sir Frank Dyson, Astronomer Royal from 1910 until 1933, whilst on the voyage home after a visit to Australia.

Frank Watson Dyson was born on January 8, 1868, and was educated at Bradford Grammar School and Trinity College, Cambridge. $\mathrm{He}$ was second wrangler in the Mathematical Tripos in 1889, and was placed in Class I, Division 2, in Part II of the Tripos in the following year. He was awarded a Smith's Prize and elected to a fellowship at Trinity College. In 1892 he was appointed to an Isaac Newton Studentship, being the second holder of the studentship, which had shortly before been endowed by Mr. Frank McClean for research in astronomy or physical optics.

In 1894 there occurred a vacancy in the post of chief assistant at the Royal Observatory, Greenwich, through the election of H. H. Turner to the Savilian professorship at Oxford, and Dyson was selected by the Astronomer Royal, W. H. M. Christie, to fill the vacancy. The choice proved to be a singularly happy one, and Dyson threw himself with characteristic energy and enthusiasm into the various branches of the work at Greenwich.

Dyson's first important work, undertaken in collaboration with W. G. Thackeray, one of the assistants, was a new edition of Groombridge's Circumpolar Catalogue. Stephen Groombridge, a retired West Indian merchant, had made at Blackheath between the years 1806 and 1819 some 27,000 observations of more than 4,000 circumpolar stars, using a $3 \frac{1}{2}$-inch aperture transit circle of 5 feet focal length. The observations had been well made, with careful attention to the instrumental adjustments, but the reductions were not in accordance with modern ideas of accuracy. A complete new reduction was made, starting from the original observing books. The Groombridge stars were re-observed at Greenwich, and from the comparison of the two series of observations, supplemented by such other observations as were available, the proper-motions of the stars were derived. These proper-motions were discussed for the derivation of the constant of precession and the solar motion. The work was completed in 1905 and provided a valuable addition to the available data on the proper-motions of the stars. The publication came at an opportune time. In the previous year Kapteyn had announced his important discovery of star-streaming from the analysis of the propermotions of the bright stars observed by Bradley in the years 1750-62. The Groombridge proper-motions were used by A. S. Eddington, who succeeded Dyson as chief assistant at Greenwich on the appointment of Dyson in 1906 as Astronomer Royal for Scotland, to confirm the existence of star-streaming amongst these fainter stars, which extended to a greater distance from the sun than the stars used by Kapteyn.

The work on the Groombridge Catalogue directed Dyson's attention to the problems of stellar motions, in relation to the distances and luminosities of the stars and to their distribution in space. Both whilst at Edinburgh and after his return to Greenwich in 1910 as Astronomer Royal, on the retirement of Sir William Christie, he published a number of papers on these subjects.

As chief assistant, Dyson had also taken a considerable part in the Greenwich share in the international co-operative plan for photographing the 